\title{
PEMBANGUNAN EKOWISATA BERBASIS KEARIFAN LOKAL DI DESA CILANGCANG, KECAMATAN CIKIJING, MAJALENGKA
}

\author{
Cece Sobarna, Taufik Ampera dan Asri Soraya Afsari \\ Fakultas Ilmu Budaya, Universitas Padjadjaran \\ E-mail: cece@unpad.ac.id
}

\begin{abstract}
ABSTRAK: Cilancang merupakan salah satu desa di Majalengka yang menyimpan beragam potensi wisata baik alam maupun budaya. Potensi wisata ini ada akan tetapi belum dikembangkan secara optimal. Oleh karena itu, diperlukan pendampingan kepada masyarakat sasaran dalam rangka menunjang pembangunan ekowisata berbasis kearifan lokal tersebut. Upaya yang ditempuh berupa pengumpulan data budaya dan alam yang ada di Desa Cilancang. Data budaya (kearifan lokal) yang dimaksud meliputi tradisi lisan, petuah, pengetahuan tradisional, upacara, pertabuan, kesenian, dan alam. Kegiatan diawali dengan metode ceramah dan demonstratif secara daring terkait pemahaman ekowisata dan kearifan lokal. Metode pendampingan dilaksanakan pada saat masyarakat sasaran mengumpulkan data di lapangan. Evaluasi hasil pendampingan dilakukan untuk mengukur tingkat keberhasilan kegiatan ini. Setelah pendampingan selesai tampak adanya perubahan sikap dari masyarakat sasaran. Kegiatan pemupuan data budaya dan alam yang difokuskan pada pengembangan ekowisata merupakan pengalaman baru bagi masyarakat sasaran. Mereka juga antusias dalam menyusun data budaya dan alam.
\end{abstract}

Kata kunci: ekowisata; kearifan lokal; pendampingan; data budaya; data alam

\section{THE DEVELOPMENT OF ECOTOURISM ON LOCAL WISDOM IN CILANCANG VILLAGE, CIKIJING SUB-DISTRICT, MAJALENGKA}

\begin{abstract}
Cilancang is one of the villages in Majalengka that holds a variety of tourism potential, both natural and cultural. This tourism potential exists but has not been optimally developed. Therefore, assistance is needed to target communities in order to support the development of ecotourism based on local wisdom. Efforts taken are in the form of collecting data on culture and nature in the village of Cilancang. Cultural data (local wisdom) includes oral traditions, advices, traditional knowledge, ceremonies, taboos, arts, and nature. The activity began with an online lecture and demonstration method related to understanding ecotourism and local wisdom. The mentoring method is carried out when the target community collects data in the field. Evaluation of mentoring results is carried out to measure the level of success of this activity. After the mentoring was completed, there were changes in the attitude of the target community. The activity of collecting cultural and natural data which is focused on developing ecotourism is a new experience for the target community. They are also enthusiastic in compiling natural and cultural data.
\end{abstract}

Keywords: ecotourism; local wisdom; assistance; cultural data; natural data

\section{PENDAHULUAN}

Secara umum ekowisata dipahami sebagai wisata berbasis alam yang menekankan pembelajaran lingkungan atau memastikan lingkungan tidak dirusak oleh wisatawan atau kegiatan wisata. Menurut Departemen Kebudayaan dan Pariwisata Republik Indonesia (2009), pengertian ekowisata seluruhnya berprinsip pada pariwisata yang kegiatannya mengacu pada lima unsur penting, yaitu 1. memberikan pengalaman dan pendidikan kepada wisatawan sehingga dapat meningkatkan pemahaman dan apresiasi terhadap daerah tujuan wisata yang dikunjunginya. Pendidikan diberikan melalui pemahaman tentang pentingnya tujuh pelestarian lingkungan, sedangkan pengalaman diberikan melalui kegiatan-kegiatan wisata yang kreatif disertai dengan pelayanan yang prima, 2. memperkecil dampak negatif yang bisa merusak karakteristik lingkungan dan kebudayaan pada daerah yang dikunjungi, 3. mengikutsertakan masyarakat dalam pengelolaan dan pelaksanaannya, 4. memberikan keuntungan ekonomi terutama kepada masyarakat lokal. Oleh sebab itu, kegiatan ekowisata harus bersifat profit (menguntungkan), 5 . dapat terus bertahan dan berkelanjutan. Berdasarkan unsur ekowisata tersebut, setidaknya terdapat empat tujuan dalam ekowisata yaitu unsur edukasi, pemberdayaan masyarakat, peningkatan ekonomi, dan upaya konservasi.

Pandangan yang diberikan oleh para ahli terkait ekowisata, di antaranya Fennell (2003) mengemukakan bahwa ekowisata adalah sebuah bentuk kelanjutan dari wisata berbasis sumber daya alam yang difokuskan pada pembelajaran serta berbagai pengalaman mengenai alam, yan g dikelola dengan meminimalisasi dampak nonkonsumtif, dan berorientasi lokal. Berikutnya, Lappo, A, dkk (2010) mendefinisikan ekowisata sebagai konsep alternatif pariwisata yang secara teratur dan tetap mengedepankan nilai-nilai alam, masyarakat, dan sosial yang memungkinkan adanya hubungan positif dari para pelakuanya.

Ahli lainnya, Goeldner (1999) dalam Butcher (2007) menjelaskan bahwa ekowisata merupakan bentuk perjalanan menuju kawasan yang masih 
alami dengan maksud untuk memahami budaya serta sejarah alami dari lingkungannya, menjaga integritas ekosistem sambil mencipatakan kesempatan ekonomi untuk membuat sumber daya konservasi dan alam sehingga memberi keuntungan bagi masyarakat lokal. Dengan demikian, dapat dipahami bahwa ekowisata bukan hanya sekadar sebuah perjalanan wisata. Dalam ekowisata terdapat pesan yang bertujuan untuk menjaga alam dari para wisatawan.

Salah satu kabupaten di Jawa Barat yang saat ini berfokus pada pembangunan kepariwisataan adalah Majalengka. Konsep pembangunan kepariwisataan merupakan bagian tak terpisahkan dari program jangka panjang yang diprioritaskan oleh Kabupaten Majalengka. Kabupaten ini terletak di sebelah timur Jawa Barat. Majalengka merupakan wilayah strategis sebab kabupaten ini merupakan penghubung empat kabupaten, yakni Sumedang, Indramayu, Cirebon, dan Kuningan. Saat ini Pemerintah Provinsi Jawa Barat tengah memprioritaskan Kabupaten Majalengka dalam pembangunan infrastruktur guna menunjang percepatan pembangunan, salah satunya melalui mega proyek pembangunan Bandara Internasional Jawa Barat yang telah dibangun di Kecamatan Kertajati. Di samping itu, Kabupaten Majalengka tengah berupaya mengembangkan diri menjadi kota bisnis dan industri. Untuk mencapai tujuan tersebut, Majalengka juga terus berbenah diri dengan mengembangkan sentra untuk relokasi berbagai industri dan konsep pengembangan Kertajati Aero City yang terintegrasi dengan berbagai fasilitas, seperti permukiman, universitas, rumah sakit, pusat perbelanjaan, bussines center, resort, sarana hiburan dan rekreasi (https://majalengkakab. go.id/profil-majalengka-2/).

Majalengka kini memiliki bargaining position tersendiri dalam hal prospek investasi. Daya dukung pembangunan Jawa Barat yang sebagian akan dipusatkan di Majalengka seperti akses jalan tol, bandara internasional, dan Aero City serta relokasi industri terutama industri tekstil akan membuat Kota Majalengka menjadi kota investasi yang sangat prospektif. Dalam lima tahun ke depan diharapkan Kota Majalengka akan berubah menjadi kota yang banyak dikunjungi oleh para pelaku bisnis baik lokal, regional, maupun internasional. Hal tersebut tentu akan berkontribusi positif terhadap sektor pariwisata.

Beberapa tempat wisata terbaru dan menarik yang dapat dikunjungi di daerah Majalengka saat ini di antaranya Jembar Waterpark yang terletak di Jalan Dukuh Jeruk, Ranjiwetan, Kasokandel, Curug Muara Jaya di Kampung Apuy, Argamukti, Argapura, Air Terjun Ibun Pelang di Desa Sukadana, Argapura, Curug Sawer yang letaknya tidak terlalu jauh dengan Curug Muara Jaya, tepatnya di Desa
Argalingga, Air Terjun Baligo di Bantaragung, Sindangwangi, dan Talaga Herang di Lengkong Kulon, Sindangwangi (https://www.itrip.id/tempatwisata-majalengka). Selain tempat-tempat wisata tersebut, daerah Majalengka lainnya yang masih memiliki dan menyimpan potensi wisata alam yang beragam adalah Desa Cilangcang. Potensi yang dimiliki di antaranya bersumber pada kearifan lokal. Secara terminologis, kearifan lokal dalam bahasa Inggris disebut sebagai local wisdom, lebih khusus lagi dalam kajian antropologi disebut sebagai local genius. Istilah ini pertama kali diperkenalkan oleh Wales ((1948) dalam Poespowardojo, 1986: 29-30). Wales memberi pemahaman bahwa kearifan lokal merupakan kemampuan kebudayaan setempat dalam menghadapi pengaruh kebudayaan asing pada waktu kebudayaan itu berhubungan (Rosidi, 2011: 29).

Sibarani (2012: 112) menjelaskan bahwa kearifan lokal terdiri atas dua kata, yaitu kearifan (wisdom) dan lokal (local). Tiap-tiap kata mengandung pemahaman masing-masing, kearifan berarti kebijaksanaan, sedangkan lokal berarti setempat. Dengan demikian, kearifan lokal dipahami sebagai gagasan dan pengetahuan setempat yang bersifat bijaksana, penuh kearifan, bernilai baik, dan berbudi luhur yang dimiliki dan dilaksanakan oleh anggota masyarakatnya.

Kearifan lokal dapat pula dipahami sebagai indentitas kultural. Hal ini sejalan dengan penjelasan Soebadio (1986: 18-19) dalam Sobarna, dkk (2019: 18) bahwa local genius yang dewasa ini terkenal dengan culural identity merupakan sebuah identitas atau kepribadian budaya suatu bangsa, yang mengakibatkan bahwa bangsa bersangkutan menjadi lebih mampu menyerap dan mengolah pengaruh kebudayaan yang mendatanginya dari luar wilayah sendiri, sesuai dengan watak dan kebutuhan pribadinya.

Cilancang merupakan salah satu desa yang terdapat di Kecamatan Cikijing, Kabupaten Majalengka. Wilayah Kecamatan Cikijing memiliki luas $43.54 \mathrm{Km}^{2}$. Luas kecamatan ini sekitar 3,6 \% dari luas wilayah Kabupaten Majalengka. Secara geografis Kecamatan Cikijing terletak di selatan Ibu Kota Kabupaten Majalengka, yaitu antara $108^{\circ} 17^{\prime}$ - $108^{\circ} 24^{\prime}$ Bujur Timur dan $6^{\circ} 57^{\prime}-7^{\circ} 03^{\prime}$ Lintang Selatan. Ketinggian tempat dari permukaan laut berkisar antara 600 - 900 (mdpl) (sumber: http:// cikijing.kec. majalengkakab. go.id/?page_id=72).

Seperti telah dikemukakan sebelumnya, Desa Cilangcang menyimpan berbagai potensi objek wisata yang perlu dibangun dan dikembangkan terutama wisata komersial air. Selama ini pemerintah desa setempat dan masyarakat sasaran berkeinginan untuk membangun potensi wisata yang ada di desa akan tetapi belum mempunyai 
gambaran untuk membangunnya. Padahal potensi wisata yang terdapat di Desa Cilangcang, terutama wisata komersial air tersebut perlu dibangun dalam upaya peningkatan jumlah objek wisata di daerah Majalengka. Selain itu, pengelolaan tempat wisata yang baik dapat berkontribusi positif terhadap peningkatan pendapatan masyarakat juga peningkatan pendapatan daerah. Program ini tentu selaras pula dengan program Kabupaten Majalengka dalam upaya peningkatan sektor pariwisata.

Permasalahan yang dihadapi berdasarkan fakta di lapangan adalah sebagai berikut: (1) pemerintahan desa dan masyarakat menyadari bahwa Desa Cilancang memiliki beragam potensi wisata yang dapat dikembangkan. Namun, beragam potensi budaya tersebut belum tergali secara optimal, (2) pemerintahan desa dan masyarakat masih banyak yang belum memahami bagaimana cara membangun ekowisata berbasis kearifan lokal di Desa Cilancang.

Kehadiran PPM dapat memberikan alternatif jalan keluar dari permasalahan yang telah dikemukakan di atas. Adapun tujuan kegiatan pengabdian kepada masyarakat dapat dirumuskan sebagai berikut: (1). menerapkan ilmu pengetahuan sesuai dengan bidang keilmuan dan etika akademik, (2). membekali pengetahuan dan wawasan tentang ekowisata dan kebudayaan lokal (kearifan lokal) kepada masyarakat sasaran guna pembangunan objek wisata di Desa Cilancang, (3) menumbuhkan pemahaman pentingnya pembangunan wisata yang bertanggung jawab terhadap alam.

\section{METODE}

Pelaksanaan pengabdian dilakukan melalui metode pelatihan dan pendampingan. Pada tahap ini dilakukan beberapa langkah kegiatan yang tidak lepas dari peran masyarakat sasaran sebagai indikator keberhasilan.

Adapun langkah-langkah yang dilakukan sebagai berikut.

Persiapan kegiatan, dalam tahap ini tim pelaksana kegiatan mempersiapkan berbagai hal untuk pelaksanaan program pengabdian kepada masyarakat. Tim pelaksana melakukan survei awal ke Desa Cilancang dan berbincang dengan Kepala Desa.

Penyediaan tempat, sehubungan dengan kegiatan pengabdian ini berlangsung pada masa pandemi Covid 19 maka metode ceramah dan pendampingan dilakukan secara daring dengan memanfaatkan perangkat teknologi yang ada, termasuk komunikasi melalui aplikasi Whatsapp. Dengan demikian, pelaksanaan pendampingan dilakukan melalui jarak jauh.

Penyusunan bahan naskah tutorial, Kegiatan pengabdian ini memanfaatkan naskah tutorial sebagai panduan dalam pengumpulan data budaya dan alam yang akan dilakukan oleh masyarakat sasaran.

Pelaksanaan kegiatan dan evaluasi, kegiatan pengabdian dilakukan melalui metode ceramah, demonstratif, dan pendampingan.

\section{HASIL DAN PEMBAHASAN}

Salah upaya yang dilakukan dalam rangka pembangunan ekowisata berbasis kearifan lokal di suatu daerah adalah melalui penggalian nilai-nilai budaya lokal yang terdapat di daerah tersebut. Nilainilai budaya tersebut meliputi data-data tradisi lisan, kesenian, dan tradisi perayaan yang telah dilakukan secara turun-temurun dan masih ada. Berdasarkan jenisnya, kearifan lokal mencakup bentuk tekstual, arsitektual, dan karya seni.

Penggalian ini penting untuk dilakukan sehubungan dengan kearifan lokal memiliki fungsi antara lain melestarikan sumber daya manusia, mengonservasi dan melestarikan sumber daya alam, mengembangkan kebudayaan serta ilmu pengetahuan, memiliki makna sosial seperti pada kegiatan upacara ritual/kerabat, memiliki makna dalam kaitannya dengan etika moral yang terwujud dalam upacara adat, dan memiliki fungsi sebagai petuah, kepercayaan, pengetahuan, dan pantangan. Dengan demikian, terdapat keterikatan antara penggalian kearifan lokal dalam menunjang terwujudnya ekowisata.

Adapun khalayak sasaran yang dianggap strategis dan tepat untuk dilibatkan dalam pelaksanaan pengabdian ini adalah perwakilan dari unsur aparat Desa Cilangcang, pemuda sebagai perwakilan masyarakat, dan LPM. Aparat desa merupakan perangkat pemerintah desa yang mempunyai kewajiban untuk membangun desa termasuk membangun potensi wisata yang ada di desa. Masyarakat desa dan LSM mempunyai peran dalam mendukung dan melibatkan diri secara aktif dalam program pembangunan potensi wisata (ekowisata) yang dicanangkan oleh pemerintahan desa. Masyarakat sasaran yang terlibat berjumlah 5 orang yang terdiri atas 3 aparat desa, 1 perwakilan masyarakat dari kalangan pemuda, dan 1 perwakilan LPM.

Kegiatan pengabdian dilakukan melalui metode pelatihan yang meliputi ceramah dan demonstratif dan metode pendampingan. Ceramah secara daring dilakukan pada saat pemaparan materi. Metode ini bertujuan untuk memberikan informasi/pengetahuan terkait pemahaman ekowisata, kearifan lokal kepada masyarakat sasaran. Setelah tim pelaksana menyampaikan ceramah kemudian dilakukan diskusi interaktif dengan masyarakat sasaran. Masyarakat sasaran cukup antusias mendengarkan 
pemaparan dari tim pelaksana dan masyarakat sasaran pun mengajukan beberapa pertanyaan yang belum dipahami terkait ekowisata dan kearifan lokal. Demonstratif secara daring dilakukan pada saat tim pelaksana menjelaskan prosedur untuk pemupuan data budaya di lapangan. Tim pelaksana menjelaskan isi naskah turorial yang berkaitan dengan data budaya (kearifan Lokal) seperti tekstual, arsitektual, dan karya seni. Data tradisi lisan, seperti sejarah lisan, dongeng, pantun, dan cerita rakyat. Data petuah seperti ungkapan dan pribahasa. Data pengetahuan tradisional seperti kerajinan, busana tradisionl, metode pengetahuan/pengobatan tradisional, makanan tradisional, dan minuman tradisional. Data upacara/perayaan seperti hajat bumi, nyawer, mitembeyan, ruwatan, nujuh bulanan, puput puser, turun taneuh, sunatan, ngeuyeuk seureuh, dan saweran. Data pertabuan/pantangan (pamali) seperti tabu, mitos, dan takhayul. Serta data kesenian seperti seni pertunjukan, seni sastra, seni musik, seni tari, seni pahat, seni lukis, seni beladiri, seni kaligrafi, seni permainan, tradisional, dan seni kriya. Naskah turorial ini menjadi panduan bagi masyarakat sasaran selama kegiatan pengumpulan data budaya dan alam di lapangan.

Di samping itu, tim pelaksana juga memberikan beberapa contoh jenis data budaya dan alam kepada masyarakat sasaran agar masyarakat sasaran tidak salah dalam mengumpulkan data yang akan mereka lakukan di lapangan. Kegiatan sedikit terkendala karena sinyal internet dari beberapa peserta (masyarakat sasaran) tidak stabil.

Selanjutnya, kegiatan pendampingan pertama, dilakukan setelah masyarakat sasaran melakukan pemupuan data budaya tahap 1 di Desa Cilancang. Pendampingan dilakukan secara daring. Dalam proses pendampingan ini masyarakat menyampaikan data-data budaya yang telah berhasil mereka kumpulkan, selanjutnya tim pelaksana membantu meluruskan klasifikasi data yang telah dilakukan oleh masyarakat sasaran.

Berikut contoh data budaya tahap 1 yang telah berhasil dikumpulkan oleh masyarakat sasaran.

\section{Jenis Data Budaya: Pertabuan/Pamali}

Data ungkapan pamali 'pertabuan' yang masih berlaku dan dipegang teguh oleh masyarakat Desa Cilancang berjumlah enam puluh lima. ungkapan pamali yang berlaku baik bagi anak perempuan maupun anak laki-laki, di antaranya ulah sok diuk di lawang bisi nongtot jodo 'jangan berdiri di depan jalan keluar masuk pintu nanti susah mendapat jodoh', ulah sok ngeureutan kuku ti peuting 'jangan memotong kuku di malam hari', ulah sok kaluar sareupna bisi aya sandekala 'jangan keluar rumah di saat matahari mulai terbenam nanti ada sandekala', dan ulah sok sare sareupna 'jangan tidur menjelang Margrib'. Ungkapan pamali yang hanya berlaku untuk anak perempuan di antaranya ulah sok lila-lila mun nganjang ka imah batur (nu keur hamil) 'orang yang sedang hamil tidak boleh berlama-lama jika berkunjung ke rumah orang lain' dan ulah sok ngadahar cau ambon awewe mah 'perempuan dilarang memakan pisang ambon'. Adapun Ungkapan pamali yang hanya berlaku untuk anak laki-laki di antaranya ulah sok nyokot beas $\mathrm{ka}$ goah $k$ u lalaki 'laki-laki dilarang mengambil beras di goah' dan ulah sok heheotan di imah bisi pare haliber 'laki-laki dilarang bersiul di dalam rumah karena akan mengakibatkan padi beterbangan'.

Kegiatan pendampingan kedua dilakukan setelah masyarakat sasaran melakukan pemupuan data budaya tahap 2 di Desa Cilancang, Pendampingan dilakukan secara daring. Data yang berhasil dikumpulkan oleh masyarakat masih berkaitan dengan data-data budaya. Dalam proses pendampingan ini masyarakat menyampaikan datadata budaya yang telah berhasil mereka kumpulkan selanjutnya tim pelaksana membantu meluruskan klasifikasi data yang telah dilakukan oleh masyarakat sasaran.

Berikut contoh data budaya tahap 2 yang telah berhasil dikumpulkan oleh masyarakat sasaran.

\section{Jenis Data Budaya: Sumber Mata Air Desa Cilangcang}

Desa Cilancang merupakan desa yang memiliki potensi wisata komersial air. Di desa ini memang terdapat banyak aliran sungai. Hal ini tidak mengherankan karena berdasarkan data yang dikumpulkan, Sebagian besarnama-nama tempat yang ada di Desa Cilancang sangat dekat dan berhubungan dengan air. Beberapa nama tempat tersebut diawali dengan kata ci, kependekan dari kata cai yang berarti 'air' dan bergabung dengan jenis kegiatan dan nama flora. Nama-nama tempat tersebut di antaranya Citamba, Cigencoy, Cikored, Cibuntu, Cipancur, Cikawung, Cidangder, Cihaliwung, dan Cisadane.

\section{Jenis Data Budaya: Kasenian Rudat}

Jenis data budaya laiinya yang terdapat di Desa Cilancang adalah kesenian Rudat. Kesenian ini merupakan kesenian yang lahir sekitar tahun 1950-an dan diturunkan dari generasi ke generasi. Dulu kesenian ini sangat terkenal sampai ke tingkat provinsi. saatitu Rudat merupakan kesenian unggulan Majalengka dan sering menjadi perwakilan untuk tampil di provinsi. Namun, seiring perkembangan zaman dan bermunculan kesenian baru maka keberadaan kesenian rudat sudah mulai pudar. Hal ini tentu saja tidak boleh dibiarkan mengingat rudat merupakan kesenian khas Majalengka termasuk 
Cilancang yang perlu diselamatkan, dilestarikan, dan dikembangkan.

\section{Jenis Data Budaya: Nyawer Budak Orok 'Sawer Bayi'}

Tradisi nyawer budak orok merupakan tradisi khas masyarakat Cilancang. Tradisi ini unik sebab tidak setiap daerah memiliki bahkan mengenal tradisi nyawer budak orok. Sampai saat ini tradisi nyawer budak orok masih dilakukan oleh masyarakat. Bendabenda yang digunakan untuk saweran meliputi permen, beras, dan uang logam/uang dalam amplop. Pada pelaksanaannya tradisi ini dilakukan oleh paraji 'dukun beranak'. Di antara sejumlah benda-benda saweran yang akan dilemparkan, terdapat permen dan uang yang dibungkus oleh daun seuereuh. Kedua benda ini lalu dikubur. Setelah dikubur paranji lalu meletakan kaki (turun tanah) sang bayi di atas tanah kuburan kedua benda saweran. Setelah itu, barulah benda-benda saweran lainnya dilemparkan dari arah tempat bayi turun tanah. Anak-anak dan orang tua yang berkumpul pun mengambil benda saweran dengan cepat. Setelah semua benda saweran dilemparkan paraji membawa sang bayi ke pintu masuk rumah sambil mengucapkan salam assalammualaikum dan berkata bade ditampi, moal? 'apakah (bayi ini) akan diterima, tidak?' Orang-orang yang berada di dalam rumah menjawab ditampi 'diterima'. Lalu sang bayi pun digendong masuk ke dalam rumah.

Kegiatan pendampingan ketiga dilakukan setelah masyarakat sasaran melakukan pemupuan data alam di Desa Cilancang. Pendampingan dilakukan secara daring. Data yang berhasil dikumpulkan oleh masyarakat berkaitan dengan data alam. Dalam proses pendampingan ini masyarakat menyampaikan data alam yang telah berhasil mereka kumpulkan. Seperti pada kegiatan pendampingan sebelumnya, pada kegiatan ini pun tim pelaksana membantu meluruskan klasifikasi data yang telah dilakukan oleh masyarakat sasaran. Data alam yang dikumpulkan berupa tempat yang berpotensi untuk dijadikan kawasan ekowisata. Salah satunya adalah Pasir Bajing. Tempat ini berpotensi untuk dikembangkan sebagai kawasan perkemahan seperti Cikole di daerah Lembang.

Berikut Deskripsi mengenai asal-usul nama tempat Pasir Bajing berdasarkan data yang diperoleh oleh masyarakat sasaran.

\section{Jenis Data Alam: Kebun Pasir Bajing}

Pasir Bajing merupakan nama sebuah kebun yang ada di Desa Cilancang. Kebun Pasir Bajing sering digunakan sebagai rumah perkemahan dalam kegiatan pelantikan organisasi siswa atau jika tidak sedang digunakan sebagai rumah perkemahan, kebun Pasir Bajing digunakan sebagai tempat menanam palawija seperti jagung, tomat, dan kacang. Luas kebun Pasir bajing sekitar setengah hektar. Nama Pasir Bajing telah lebih dari puluhan tahun digunakan sebagai nama kebun ini. Kebun Pasir Bajing terletak di sebelah Barat Balai Desa Cilancang. Kebun ini diberi nama Pasir Bajing sebab sering dipakai sebagai tempat pelarian bajing luncat 'maling' atau pencuri. Dulu bajing luncat sering bersembunyi di sana terkadang tempat tersebut dipakai sebagai tempat menyimpan barang-barang curian. Barang-barang yang sering ditemukan seperti seng, TV. dan tape. Kini, kebun Pasir Bajing sudah jarang digunakan baik sebagai tempat berkemah maupun tempat anak-naka bermain bola. Sudah 5 tahun tempat ini digunakan sebagai tempat menanam palawija sesuai dengan musim tanamnya. Sampai saat ini Pasir Bajing sudah menjadi tempat yang aman, tidak pernah digunakan lagi sebagai tempat persembunyian bajing luncat.

Pendampingan keempat berupa evaluasi kegiatan yang dilaksanakan setelah semua data budaya dan alam berhasil dikumpulkan dan diklasifikasi. Evaluasi yang dilakukan mencakup: 1. evaluasi materi terkait ekowisata dan kearifan lokal; 2. pendampingan terhadap hasil pemupuan data budaya dan alam yang telah dilakukan oleh masyarakat sasaran. Dalam kegiatan evaluasi ini masyarakat sasaran mulai menyusun data-data budaya dan alam yang telah dikumpulkan dengan tetap mendapat pendampingan dari tim pelaksana kegiatan pengabdian. Penyusunan data budaya dan alam ini penting dilakukan guna memperoleh hasil utuh potensi data budaya dan alam yang dimiliki oleh Desa Cilancang.

\section{SIMPULAN}

Pendampingan penggalian data-data budaya dan alam dalam upaya pengembangan ekowisata di Desa Cilancang kepada unsur aparat Desa Cilangcang, pemuda sebagai perwakilan masyarakat, dan LPM merupakan pengalaman baru bagi masyarakat sasaran. Selama ini masyarakat sasaran belum pernah melakukan kegiatan pemupuan data budaya dan alam yang difokuskan pada pengembangan ekowisata. Melalui pendampingan ini, antusias masyarakat sasaran terhadap potensi budaya dan alam di Desa Cilancang, Kecamatan Cikijing, Kabupaten Majalengka yang selama ini belum terungkap diharapkan dapat terus meningkat sehingga data-data budaya dan alam dapat digali secara optimal. Melalui kegiatan ini dapat dijalin pula kerja sama antara masyarakat akademis dan masyarakat umum. Kegiatan pengabdian ini perlu dilakukan secara berkesinambungan mengingat 
pembangunan ekowisata merupakan program pembangunan berkelanjutan yang melibatkan masyarakat langsung dengan memanfaatkan potensi budaya yang ada. Program pengabdian berikutnya dapat berupa pemberian pemahaman edukasi dan konservasi mengenai ekowisata kepada masyarakat sasaran. Dengan demikian, permasalahan yang selama ini mengemuka dapat dipecahkan satu demi satu.

\section{UCAPAN TERIMA KASIH}

Kami mengucapkan terima kasih kepada seluruh pihak yang telah turut membantu dalam setiap tahapan kegiatan yang dilakukan sehingga kegiatan pengabdian ini dengan memanfaatkan berbagai perangkat teknologi yang ada dapat berjalan kendati berlangsung dalam masa pandemi Covid 19. Ucapan terima kasih kami sampaikan kepada Rektor, Dekan FIB, Direktur DRPMI, dan Mariskem FIBUniversitas Padjadjaran yang telah memfasilitasi program PPM-HIU. Ucapan terima kasih disampaikan pula kepada Kepala Desa Cilancang, Bpk. Asep Iswandar Saputra, S.Sos. dan masyarakat sasaran.

\section{DAFTAR PUSTAKA}

Butcher, J. (2007). Ecotourism, NGO's, and Development: A Critical Analysis. Routledge: New York.

Fennell, David A. (2003). Ecotourism: An Introduction. Second Edition. Routledge: New York.
Laapo A., Fahrudin, A. Bengen, D. G., dan Damar A. (2010). Kajian Karakteristik dan Kesesuaian Kawasan mangrove untuk Kegiatan Ekowisata Mangrove di Gugus Pulau Togean Taman Nasional Kepulauan Togean. Fakultas Pertanian Universitas Tadulako: Palu.

Peraturan Pemerintah Republik Indonesia No. 9 Tahun 2010 tentang Kepariwisataan.

Rosidi, Ajip. 2011. Kearifan Lokal dalam Perspektif Budaya Sunda. Bandung: Kiblat Buku Utama.

Sibarani, Robert. (2012). Kearifan Lokal: Hakikat, Peran, dan Metode Tradisi Lisan. Jakarta: Asosiasi Tradisi Lisan (ATL).

Sobarna, Cece, Yuyu Yohana Risagarniwa, Gugun Gunardi, Sutiono Mahdi, Puspa Mirani Kadir. (2019). Pembinaan Keragaman Budaya (Kearifan Lokal Masyarakat Sunda) dalam Rangka Pelestarian Lingkungan Hidup dan Ekowisata Terkait dengan Toponimi di Wilayah Palabuhanratu, Sukabumi. Jurnal Pengabdian kepada Masyarakat, 4, (1), 17-23.

https://majalengkakab.go.id/profil-majalengka-2/ (diunggah (20 Agustus 2020).

(https://www.itrip.id/tempat-wisata-majalengka (20 Agustus 2020).

(http://cikijing.kec.majalengkakab.go.id/?page id=72 (20 Agustus 2020). 